\title{
Government Policy and Internationalisation of Universities: The Case of International Student Mobility in South Korea ${ }^{1}$
}

\author{
Ki-Seok Kwon ${ }^{2}$
}

During the last a few decades, internationalisation of universities has emerged as an important issue not only in developed countries but in developing countries. South Korea as a fast catch-up country has experienced a remarkable change in its higher education system. This change is largely related to the South Korean government's higher education policy and to economic developmental stages. Against this backdrop, in order to assess the internationalisation of Korean higher education, we focus on international student mobility rather than other criteria such as infrastructure or programmes for international students and faculties. According to the recent statistics, the number of inbound foreign students involved in Korean higher education has increased significantly since 2005. Nevertheless, compared to other OECD and Asian countries, the number of outbound students in Korean higher education is high, whereas the number of inbound foreign students in higher education in Korea is very low. Against these observations, Korean government's recent policies and efforts of Korean universities to improve internationalization are discussed. Finally, some policy implications are put forward.

\section{Introduction}

Along with the powerful socio-economic forces of globalization, the internationalisation of higher education has been gaining momentum during the last few decades. According to Knight (2005), this internationalisation involves the integration of research, the use of English as the lingua franca for academic communication and the growing international labour market for scholars. In other words, it is the process of weaving academic programmes, institutions and their quality into a global context.

The internationalisation of higher education involves two goals: one is joining the firstrate education level, and the other is bilateral openness (Park, 2009). In order to accomplish both goals, two strategies are crucial for the South Korean (hereafter, Korean) higher education system. Firstly, it is pivotal to benchmark the top-ranking overseas universities and to internalise the best practices considering idiosyncratic properties of the Korean university system. Secondly, strategic alliances with first-class overseas universities are also necessary. In this way, Korean

\footnotetext{
${ }^{1}$ An earlier version of this paper was presented at UNESCO Regional Seminar on International Mobility of Students, 22-24 March 2011, Bangkok, Thailand.

2 Assistant Professor, School of Business, Kyungil University, South Korea
} 
universities can provide a high quality of education, maintain recognition, and promote the inbound movement of international students.

Recently, while scholars have noted the prominent growth of cross-border higher education in Europe, they have also noted an increased interest in the internationalisation of higher education in Asia as well as in political and economic co-operation. In particular, student mobility has tended to increase in Korea.

During the last half century, Korean universities have experienced tremendous change, both quantitatively and qualitatively. The number of universities, academic faculties and students has increased at a rapid rate compared to both developing countries and developed countries. For example, according to the enrolment rates of each stage, Trow (1974) suggested three stages of development of higher education: elite (less than 15 percent), mass (between 15 percent and 50 percent) and universal (more than 55 percent). Based on his definition, Korean higher education has moved from the "elite phase" to the "universal phase" within only three decades.

From the early stage of catch-up, the Korean government has been a dominant actor influencing the growth of the university system as well as of industry (Kwon, 2011). In particular, through the provision of technically skilled labour and qualified scientists and engineers, Korean universities have been continually encouraged to play a role as human resource suppliers for economic growth. In the 1990s, the government adopted a series of policies for strengthening universities' research activities, and recently Korean universities began to gain recognition as direct contributors to the nation's economic development.

The trend of internationalisation in higher education, combined with related government policies, brought to light international mobility as an important issue. This study aims to examine the international mobility of higher education institutions in Korea within the historical context of government policies implemented during the last few decades. The paper also addresses the efforts of individual universities and current policies related to the student mobility issue.

\section{Change of Korean Government's University Policies}

This section suggests a categorization based on the development of the Korean government's university policies. Kwon (2009) discusses the various responses of Korean universities according to their different policy environments.

Strong regulation of the education system for economic take-off (1960s - mid 1970s)

In the aftermath of Park Chung-Hee's military coup in 1961, strong regulation of the national system as well as the education sector characterizes the 1960s and 1970s (Lee et al., 1998). In this period, acting as a supplier of technical labour, especially through vocational education and training, was considered the main role of the secondary and tertiary education systems; access to universities was limited (Kim and Lee, 2006; Lee et al., 1998). In particular, in addition to encouraging an increase in the supply of human resources to the fields of science and engineering, overall government control over public and private universities was based on strong policy measures such as fixed numbers of students.

Based on the fixed number policy, large national universities in different regions were strongly supported. As mentioned earlier, the government regarded the imbalanced development between the capital area and other regions as a serious problem stemming from 1950s policies related to the economy and education. By increasing the quota for enrolled students at regional 
universities, the government aimed both to reduce the concentration of students in the capital area and to attract them to regional universities.

In terms of highly qualified scientists and engineers, the strong dependence on overseas institutions started during this period. In the 1950s, the government began to encourage overseas training supported by foreign scholarships, and initiated an official support programme for students to study abroad in 1954. These initiatives were possible due to United States aid just after the Korean War. In the 1960s and 1970s, the training of highly qualified scientists and engineers was motivated both by these government initiatives and individual demand for higher education at overseas institutions (Kim, 1997). Half of these students studied science and engineering and most of them attended institutions in the United States.

\section{Massive expansion of the higher education system (late 1970s to 1980s)}

In the aftermath of the coup in 1980, General Chun Doo-Hwan succeeded Park Chung-Hee. In light of the vulnerable political legitimacy of the government, a series of distinctive reforms of the education system were implemented (Lee et al., 1998). The most significant characteristics of this period are the massive expansion of the university system and the relaxation of the previously strong regulation of universities, in order to meet the explosive demand for higher education (Kim and Lee, 2006). However, the expansion occurred mainly in terms of the number of students in non-technological disciplines such as the humanities and social sciences, whereas in the previous period, vocational training in the fields of science and engineering was stressed (Cho et al., 2002).

Around the end of the 1970s, the strong regulation policy based on fixed numbers of students faced a few challenges due to the explosion in demand for higher education. For a long time, personal education had been considered as a significant factor for the success of members of Korean society, an attitude that can be traced back to Confucianism (Lee, 2006). Furthermore, as the national economy grew, households accumulated enough wealth to pay tuition fees, and industry came to need more qualified personnel. More directly, the sudden increase of potential entrants (i.e. graduates from secondary education) in the previous period also contributed to the explosive demand for tertiary education. As a result, the demand for higher education increased throughout the society (Lee et al., 1998).

\section{Liberalization and globalization (1990s - present)}

In 1988, the direct vote system for presidential elections resumed in response to popular pressure; and in 1993 a leader of the democratic movement, Kim Young-Sam, was elected as president. Following this, a series of educational reforms as well as political ones were implemented. Democratization in the 1990s sped up the deregulation of education policy and as a result it became easier to establish higher education institutions. In other words, the previous "permission" policy was replaced by the minimal "condition" policy for the establishment of new higher education institutions.

For example, one of the most distinctive education reforms was the abolition of the quota system for higher education institutions (except for those in the capital area) in 1995 (Kim and Lee, 2006). This led to the creation of numerous higher education institutions, not only typical small- and medium-sized private universities in regional areas but also new forms of institutions, such as graduate schools without undergraduate students, and online universities. This reform 
also encouraged large private universities in Seoul to create a dozen local autonomous campuses. This increase can be regarded as the second explosion in the number of universities as well as in the number of students enrolled. Between 1990 and 1993, twenty new four-year universities were created.

Moreover, the establishment of the World Trade Organization (WTO) in 1995 had significant influence on Korean higher education, especially on the internationalisation policies. In 1996, the "Initial Plan for Opening the Higher Education Market to Foreign Countries" was announced by the Korean government in anticipation of the upcoming WTO negotiations. In this vein, the neo-liberal higher education reform based on a market-friendly approach was set up. During the Asian financial crisis of the late 1990s, Korea's internationalisation reached a new phase. Shifting away from policies focusing on deregulation, the Korean government put an emphasis on the financial aspect of higher education by exerting an effort to attract foreign students to study in Korea and to hinder domestic students from studying abroad. Now that Korea was situated in a transitional period in which the freshman enrolment quota exceeded the eighteenyear-old population (a phenomenon induced by the falling birth rate over the previous two decades), Korean higher education institutions saw the internationalisation of higher education as a survival strategy and endeavoured to target the international market to recruit students from abroad (Byun, 2010).

\section{Assessment of Internationalisation of Korean Universities}

This section mainly focuses on two topics: government policies and universities' responses to the policy measures. First, however, a framework for assessing the two topics is introduced.

\section{Evaluation of internationalisation of higher education}

In assessing the degree of internationalisation of higher education, it is critical to determine what kind of index for analysis should be used. Lee et al. (2001) comprehensively outlines three general analysis criteria: infrastructure of international education, internationalisation programmes and human resources. Firstly, under the infrastructure of international education category, whether institutions in charge of the internationalisation education, international education or international co-operation are established or not can be one criterion. In addition, the number of foreign books and journals that the university has in its library is an important determinant of the quality of the infrastructure supportive of international education.

Secondly, internationalisation programmes are related to the university's exchange agreements with other universities abroad. Even though individual researchers at a university can privately contact other researchers overseas, these agreements between universities facilitate international co-operation, which means creating a more collaborative environment for the internationalisation of higher education. With such agreements, co-research can be pursued with foreign universities or foreign research institutes. As for domestic students, instituting a cross registration system with foreign universities offers a good cause to go abroad to get a higher education. At the same time, it creates more opportunities for foreign students to come to Korea. Internationalisation programmes also include university courses conducted in English. For students from countries where English is not the native language, a large number of subjects need to be offered in order to attract more foreign students to those countries. 
Thirdly, the human resources criterion assesses the degree of internationalisation. This standard is divided into professors and students. The former comprises the number of papers published in foreign journals, participation in academic societies overseas, participation in foreign research projects, and exchange of professors. The latter is related to the number of exchange students sent overseas. Attracting foreign students is also included in this category.

\section{Assessment of Korea's internationalisation of higher education}

With these criteria, understanding Korea's state of internationalisation of higher education is possible. As mentioned earlier, it is clear that the number of inbound foreigners in higher education has been dramatically increasing since 2000. Since the mid-1990s, interest in internationalisation of education has gained strength among universities in Korea. The number of Korean universities which had installed departments in charge of international education and international exchange was 44 out of 55 (80 percent), and most of them planned to install permanent offices in 2000 (Lee et al., 2000).

Internationalisation programmes showed great progress in that a cross registration system with foreign universities was implemented by many Korean universities. According to Lee et al. (2000) among the responding universities, 92.5 percent had already implemented such a system or would have introduced a cross registration system in 2000. This activation of internationalisation programmes not only affects the number of inbound foreign students, but also that of outbound domestic students. In addition, based on the report of the Korean Council for University Education (KCUE), the proportion of doctorates in the university academic profession was measured as 82.9 percent in Korea in 2000. Among these working at universities, approximately 40 percent acquired Ph.D.'s from abroad (KCUE, 2003). This numerical value implies that a large proportion of domestic students study abroad to get a higher education.

Regarding international human resources, the number of foreign academics working in Korean universities is still insignificant despite rising slowly for the last decade. In 2001, the ratio of foreign academics only accounted for 2.9 percent out of all university academics in Korea although 89.3 percent of universities had employed foreign faculty by 2000 (Lee et al, 2000; Kim, 2005). In other words, there are few foreign scholars teaching in Korean universities. What is noticeable is that 49.6 percent of those foreign academics were Americans, followed by Canadians and Japanese (Kim, 2005). Intense concentration of Americans and Japanese academics is partly due to the inclination of Korean students to study in the United States or in Japan.

According to Kim (2006), one of the major international factors in Korean universities is student exchange programmes established through partnerships with foreign institutions. In the survey data shown by Kim, 89.9 percent of Korean universities see internationalisation as increasing the opportunities for their students to meet and work comfortably with foreigners. In this vein, overseas student mobility has emerged as an important factor for the internationalisation of Korean universities. Moreover, compared to the first two criteria (i.e. infrastructure and programmes), the mobility of human resources shows the change in internationalisation of higher education more sensitively. Accordingly, this issue is addressed in the following section separately. 


\section{Student Mobility in Korea}

As the country's birth rate dropped over the previous two decades, it caused a decrease in the freshman-age population (Choi, 2008). The eighteen-year-old population is projected to shrink dramatically after 2010 and the enrolment quota is predicted to be equal to the freshman-age population in 2020 (Figure 1). After 2020, the eighteen-year-old population will lag far behind the total enrolment quota. Thus, the gap between the enrolment quota and the freshman-age population will be so aggravated that it is estimated to be -23.4 percent in 2023 . The encouragement of international student mobility, especially of inbound foreign students, could be a reasonable solution to this shrinking freshman-age population. Consequently, it is important for the government to enforce effective policies in order to make up for this lack of enrolment.

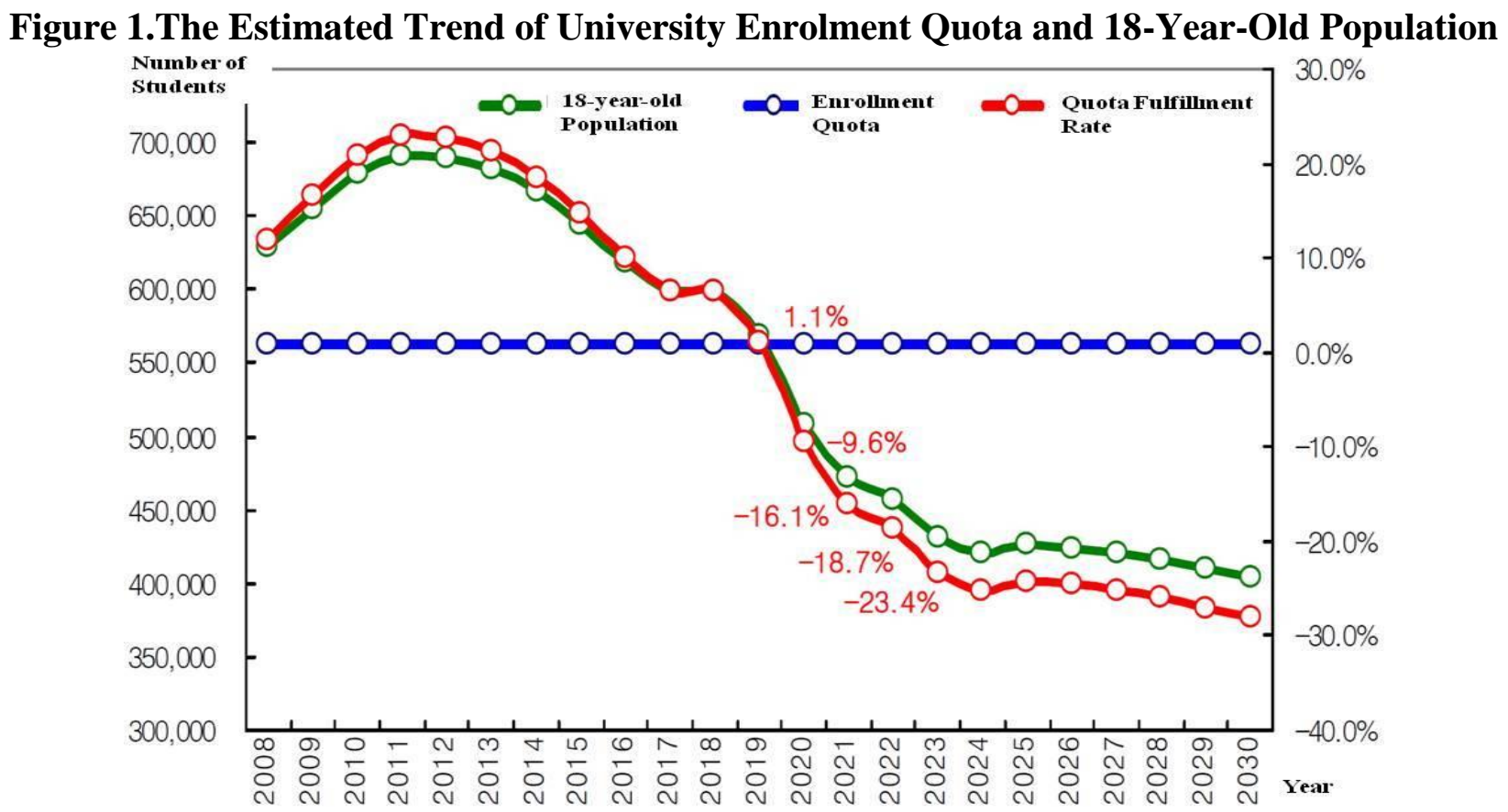

Source: Park, Jaeyoon et al. 2010. Research on the Educational Vision toward Future Education.Korean Educational Development Institute.

The population and enrolment rate of inbound foreign students involved in Korean higher education are both experiencing continuous growth. During the period from 1980 to 2000, the foreign student population was no more than a few thousand, and the ratio of foreign students remained low ( 0.1 percent or 0.2 percent) throughout this period. However, there has been a dramatic increase of inbound foreign students since 2005 . Their number is growing by 0.3 percent on average every year since 2005. Moreover, the sharp rise in the number of foreign students can be easily noted because the figures since 2005 were measured every year, not every five years, as was previously done. Comparing only the figures from 2000, 2005 and 2010 (respectively 0.1, 0.6 and 2.3 percent) indicates a great inflow of foreign students to Korea in recent years.

In addition, the types of foreign students who have come to Korea are increasingly diverse. In the past, overseas students were mostly enrolled in degree programmes. While this is still the case, there is an upward trend of foreign students coming to Korea for language studies. Compared to the students enrolled in degree programmes in 2005, by 2010 the actual number of 
foreign students in Korea had increased by four times. In particular, there has been a steep rise in inbound foreign students registered in language studies since 2007.

Table 1. Number of Inbound Foreign Students Per Year

\begin{tabular}{|c|c|c|c|c|}
\hline Year & $\begin{array}{l}\text { Total } \\
\text { Sum }\end{array}$ & $\begin{array}{l}\text { Ratio of Foreign Stu- } \\
\text { dents }\end{array}$ & $\begin{array}{l}\text { Degree Pro- } \\
\text { grammes }\end{array}$ & Language Studies, etc \\
\hline 1980 & 1,015 & 0.2 & 1,015 & - \\
\hline 1985 & 910 & 0.1 & 910 & - \\
\hline 1990 & 2,237 & 0.2 & 2,237 & - \\
\hline 1995 & 1,983 & 0.1 & 1,983 & - \\
\hline 2000 & 3,963 & 0.1 & 3,963 & - \\
\hline 2005 & 22,526 & 0.6 & 15,577 & 6,949 \\
\hline 2006 & 32,557 & 0.9 & 22,624 & 9,933 \\
\hline 2007 & 49,270 & 1.4 & 32,056 & 17,214 \\
\hline 2008 & 63,952 & 1.8 & 40,585 & 23,367 \\
\hline 2009 & 75,850 & 2.1 & 50,591 & 25,259 \\
\hline 2010 & 83,842 & 2.3 & 60,000 & 23,842 \\
\hline
\end{tabular}

Source: KEDI. 2010. Sourcebook of Statistics Analysis in Education in 2010. Korean Educational Development Institute.

Figure 2. The Number of Inbound Foreign Students per Year

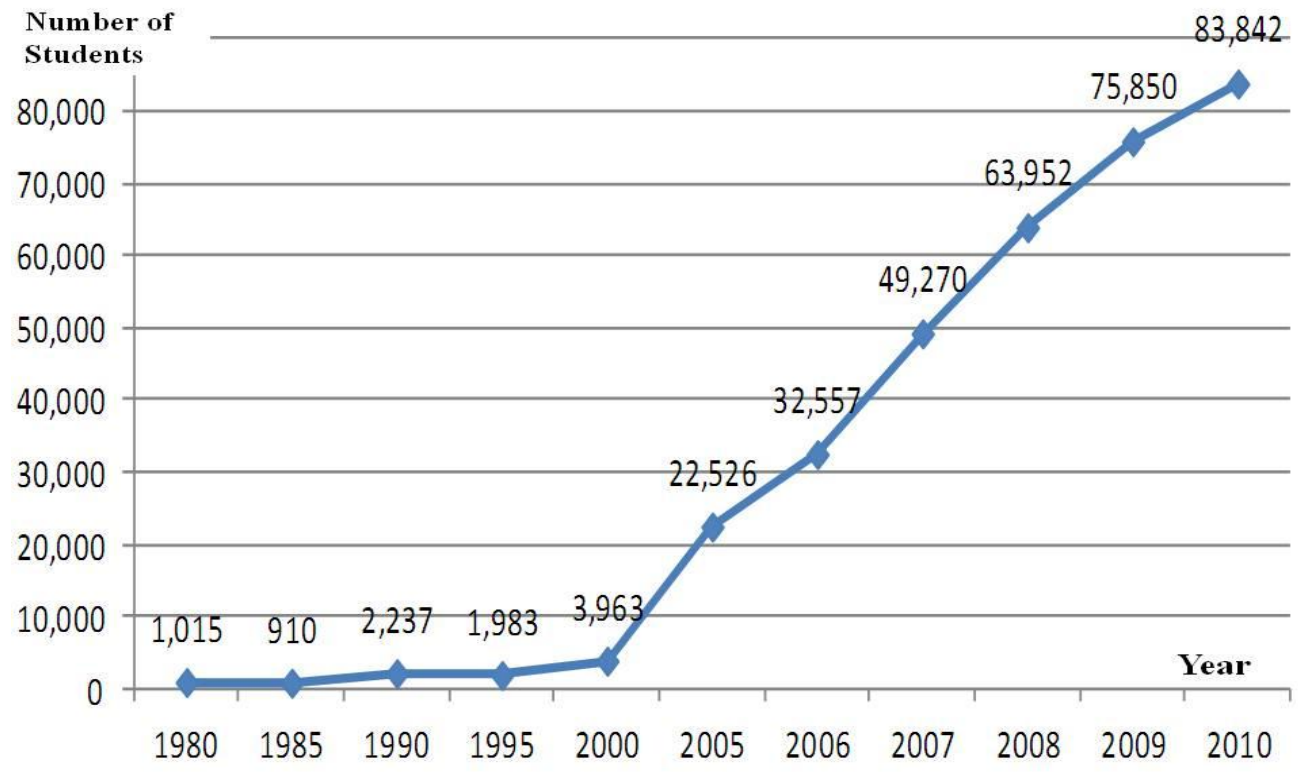

Source: KEDI. 2010. Sourcebook of Statistics Analysis in Education in 2010. Korean Educational Development Institute. 
Figure 3.The Ratio of Foreign Students at the Higher Education Level and the Index of Ratio Change of Foreign Students in 2008

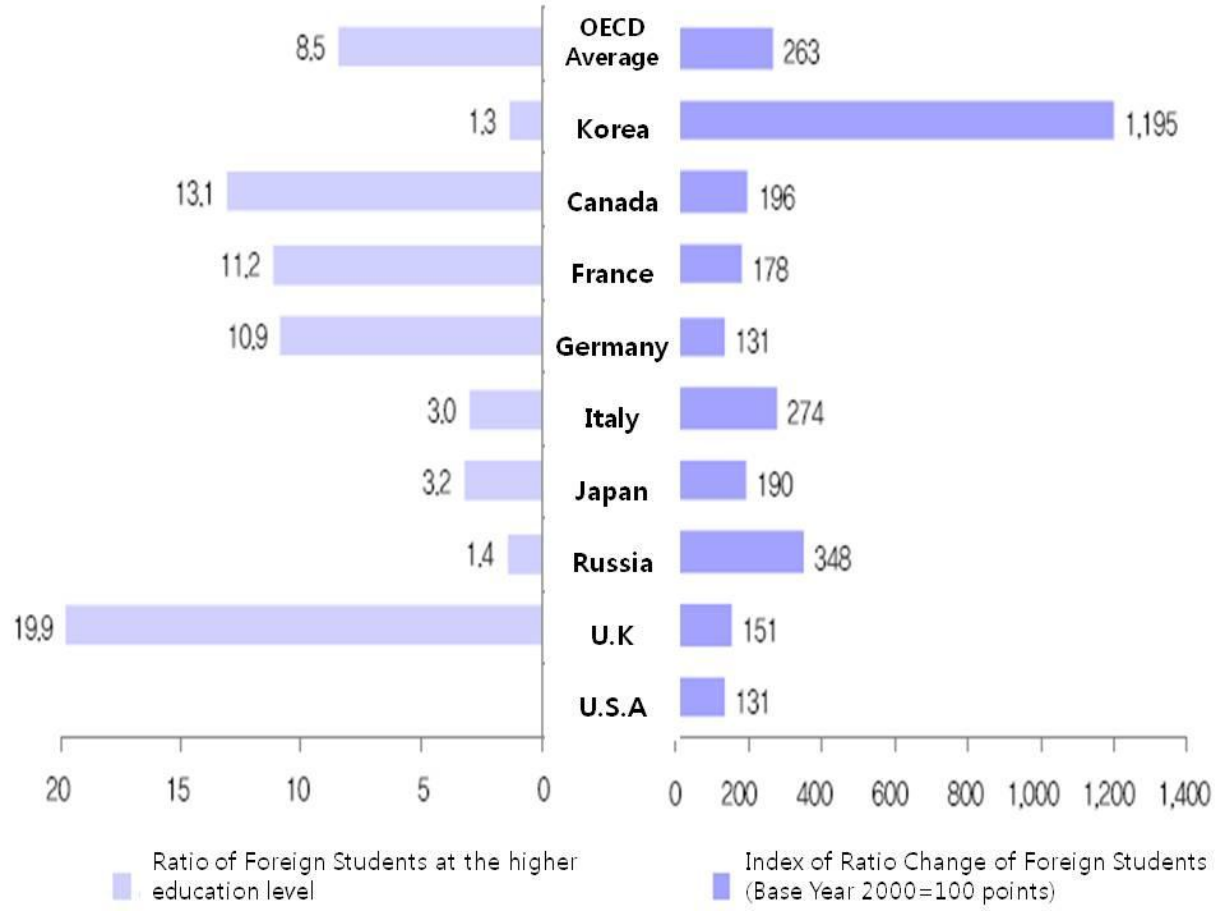

Source: KEDI. 2010. Sourcebook of Statistics Analysis in Education in 2010. Korean Educational Development Institute.

Figure 3 represents the ratio of foreign students at the higher education level and the index of ratio change of foreign students in 2008. Compared to the OECD average regarding the ratio of foreign students at the higher education level, the proportion of foreign students who received higher education in Korea was only 1.3 percent. The United Kingdom, on the other hand, had the highest ratio (19.9 percent) of foreign students at the higher education level. The average ratio of foreign students among OECD countries was 8.5 percent. This figure suggests that Korea needs to exert greater efforts to internationalise its higher education system.

The index of ratio change of foreign students shows that Korea has struggled to attract more foreign students. The index sets 2000 as the base year with 100 points, and each numerical value indicates the ratio change in the number of foreign students. Surprisingly, while OECD countries' average was 263, Korea's was recorded at 1,195, and it held an unrivalled status among other OECD countries. It can be said that Korea made strong efforts to internationalise its higher education institutions from 2000 to 2008. Therefore, although the ratio of foreign students in Korean higher education is still low, Korea possesses infinite potential to improve its higher education toward internationalisation.

We have seen the overall increase in foreign students who come to Korea for higher education. In order to closely approximate international student mobility, it is critical to conduct a comparative study with other countries by studying the figures of inflow and outflow of students in higher education. The following compares the number of inbound foreign students in higher education per thousand and that of outbound students in higher education per thousand in Korea with the same figures for other Asian countries and European countries. 
Table 2. Comparison with other Asian Countries

\begin{tabular}{|l|l|l|l|l|l|l|}
\hline & Korea & Hong Kong & Singapore & Japan & China & Taiwan \\
\hline $\begin{array}{l}\text { Number of inbound for- } \\
\text { eign students in HE }\end{array}$ & 0.66 & 0.91 & - & 0.99 & 0.03 & 0.67 \\
\hline $\begin{array}{l}\text { Number of outbound } \\
\text { domestic students in HE }\end{array}$ & 2.17 & 1.73 & 3.97 & 0.43 & 0.32 & 1.52 \\
\hline
\end{tabular}

*The numbers are calculated per thousand people, HE: Higher Education.

Source: KEDI. 2010. Sourcebook of Statistics Analysis in Education in 2010. Korean Educational Development Institute.

In comparison with other Asian countries, the number of outbound students in higher education per thousand people in Korea was, at 2.17, second to Singapore. However, the number of inbound foreign students in higher education per thousand in Korea was very low, with a value of 0.66 . This is partially related to the fact that talented Korean students are more likely to study abroad instead of pursuing higher education domestically. Furthermore, considering that Hong Kong's number of inbound foreign students in higher education per thousand at 0.91, Korea lags behind Hong Kong in the internationalisation of domestic education. In fact, more foreign students coming to a country means that they tend to seek more opportunities and convenience in terms of language, selection of English courses and so on. Thus, the high proportion of foreign students in Hong Kong compared with other Asian countries, including Korea, results from the fact that Hong Kong has internationalised domestic higher education for many years.

In Table 2, another noticeable point is that Japan shows a result opposite to Korea's. While Japan's inbound student population per thousand is merely 0.99 , its outbound student population per thousand is recorded as 0.43 , which is the highest among Asian countries and even higher than Hong Kong. That is, Japanese students have a strong tendency to get higher education in their country rather than abroad. Also, since it has a low number of outbound domestic students, it is surprising that Japan shows a high ratio of inbound foreign students at the same time.

Table 3. Comparison with European Countries

\begin{tabular}{|l|l|l|l|l|l|l|}
\hline & Korea & Denmark & Finland & Sweden & Switzerland & Iceland \\
\hline $\begin{array}{l}\text { Number of inbound for- } \\
\text { eign students in HE }\end{array}$ & 0.66 & 2.33 & 1.9 & 2.41 & 5.07 & - \\
\hline $\begin{array}{l}\text { Number of outbound stu- } \\
\text { dents in HE }\end{array}$ & 2.17 & 0.92 & 1.13 & 1.49 & 1.39 & 8.05 \\
\hline
\end{tabular}

*The numbers are calculated per thousand people, HE: Higher Education.

Source: KEDI. 2010. Sourcebook of Statistics Analysis in Education in 2010. Korean Educational Development Institute.

Table 3 shows Korea's and European countries' numbers of inbound foreign students in higher education per thousand and that of outbound students in higher education per thousand. Except for Iceland, Korea recorded the highest number of outbound students per thousand, with 2.17, whereas other European countries such as Denmark and Finland maintained approximately 1.00. Korea's relatively low number of inbound overseas students indicates that most of the European countries attract more foreign students. For instance, the inbound foreign student population is as many as 5.07 people per thousand in Switzerland. This value is much higher than Switzerland's outbound figure, which is 1.39. In other words, it signifies that Switzerland's higher education is 
highly internationalised and is more attractive for international students than Korean higher education.

Generally, in Asian countries the number of inbound foreign students in higher education is low, whereas the number of outbound domestic students is relatively high, except in Japan. In European countries, the trend is opposite. Those countries had more inbound foreign students than outbound domestic students. Setting aside Switzerland, where international students' mobility is particularly strong, the inflow and outflow of students in European countries tends to be counterbalanced. That is to say, the gap between the number of inbound and outbound students is narrower than that of Asian countries.

Figure 4.Ratio of International Students in Higher Education per Country

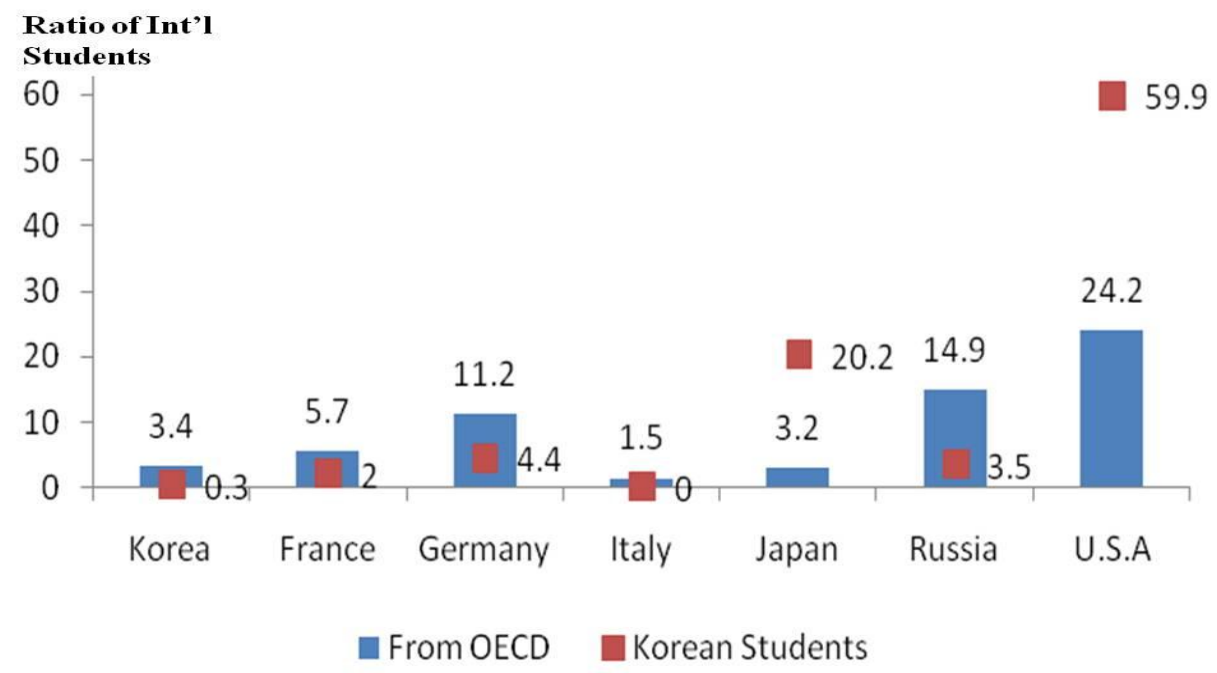

KEDI. 2010. Sourcebook of Statistics Analysis in Education in 2010. Korean Educational Development Institute.

It is also necessary to understand the trend of outbound domestic students since Korea recorded a high numbers of them going abroad for higher education. Figure 4 shows the ratio of international students per country in higher education. This is helpful to discern which countries Korean students mostly go to in order to study abroad. Korean students are asymmetrically apt to go to the United States and Japan for higher education. While the ratio of OECD international students going to the United States is 24.2 percent, 59.9 percent of Korean students studying abroad go to the United States, which is twice the OECD average. In the case of Japan, the difference between the OECD average and Korea's average is greater. The ratio of Korean students going to Japan is 20.2 percent, which is second after the United States. The ratio of OECD students is only 3.2 percent.

Moreover, although the ratio of Korean students who get a higher education in Japan and in the United States is conspicuously high, the level of Korean students going to other countries remains low compared to the OECD average. For instance, the ratio of international students in higher education in Russia is 14.9 percent, which is third following the United States and Germany. However, in Korea, that ratio is barely 3.5 percent. This indicates that Korean students rarely go overseas to countries other than Japan or the United States for a higher education. In other words, their range of international mobility is limited to those two countries within OECD 
countries. Outside of OECD countries, China has emerged as a popular destination for Korean students recently.

\section{Discussion and Conclusion}

\section{Recent Korea's policy for internationalisation of higher education}

One of the most famous higher education policies for internationalisation in Korea is the Brain Korea 21 Project (BK 21 Project), which was active between 1999 and 2005. The goal was to apply new rules of competition among universities in setting the amount of national research funds and to introduce a new evaluation system for the academic performance of universities. Over seven years, 1.2 billion USD dollars was invested (Kim, 2005). The BK 21 Project emphasized the achievement of getting more global recognition for Korean research especially through publication in academic journals and citations in Science Citation Index (SCI) (Byun, 2010). According to the Ministry of Education, BK21 contributed to an increase in SCI-level publications by Korean academics.

With the increase in the number of Korean scholars' papers from the BK 21 Project, the Lee MyungBak administration launched the World Class University Project (WCU Project) in 2008. Its goal was to hinder Korea's brain drain and to attract more well-known scholars to Korea. Also, this project encouraged new academic programmes in growth-generating fields such as nanotechnology as well as collaboration with foreign academics (Byun, 2010).

\section{Efforts of Korean universities}

While establishing partnerships with international higher education institutions, one of the other approaches to internationalisation is offering courses in English. According to data provided by the KEDI, 120 schools have internationally related programmes. The development of an internationalised curriculum can be a good way to achieve reforms in diversification and specialization. In addition, the establishment of "international" graduate schools will bring stronger competitiveness to Korean universities' academic programmes. The idea of establishing international graduate schools was presented around the mid-1990s, when Korea was negotiating an agreement for the terms of trade in services and agricultural products with the United States (Kim, 2006).

As an example of these efforts to improve the competitiveness of universities in attracting foreign students, Korea University, one of the biggest private universities in Korea, employs a variety of strategies to promote its internationalisation. First, in order to establish a firm information infrastructure, it has carried out the creation of e-library and wireless networks on campus. This has created a good environment for scholars and students. Second, Korea University has taken measures to expand English courses. In fact, 31 percent of all lectures were done in English in 2006, and the school plans to increase this number (Ahn, 2006). This development attracts a greater number of prominent visiting scholars and exchange students from overseas.

Moreover, the establishment of a Global Korea University Campus is being discussed. In order to send a large number of students overseas with minimal complications, the university is making agreements with foreign universities. These will provide an opportunity for Korean students to experience high quality higher education overseas, while providing infrastructure such as building dormitories for the exchange students.

April/May 2013 | 45 
Globalization has triggered the internationalisation of higher education. International student mobility has been facilitated and many students have studied abroad to get a quality higher education. Korea is not an exception to this global trend. Korean students have studied abroad for a long time. The number of outbound students shows no sign of declining. This can result in a brain drain and loss of human resources for the country. However, recently, the "brain circulation" perspective is gaining currency which means that outbound students return to Korea to contribute to nation building. Also, in response to the expected deficit in the registration quota in the future due to the falling birth rate in Korea, higher education institutions have focused on attracting foreign students to Korea. As a result of such efforts, the population of inbound foreign students has increased since 2000, and it continues to progress steadily.

The internationalization of higher education diversifies academic programmes and institutional types. These encourage efficiency, productivity and quality within the higher education system. In addition, Korea's competitiveness with other universities in the world will be enhanced to a great extent if internationalization is strengthened. Thus, in the long run, internationalization will attract more foreign students to Korea while encouraging domestic students to study in Korea rather than abroad. That is, domestic students will be able to receive an almost equal level of higher education without going to other countries, because internationalisation causes not only international student mobility but faculty member mobility.

\section{References}

Ahn, M. 2006. The Current Issues and Tasks of Internationalisation of Higher Education. Keynote Presentation at Conference of Higher Education Institute, Korea University, Seoul, Korea.

Altbach, P.G and Knight, J. 2007. The Internationalisation of Higher Education: Motivations and Realities. Journal of Studies in International Education, Vol. 11, No. 3/4, pp.290-305

Byun, K. and Kim, M. 2010. Shifting Patterns of the Government's Policies for the Internationalisation of Korean Higher Education. Journal of Studies in International Education, Vol. 15, No. 5, pp.467-486.

Cho, H., Lee, E., Lee C. and Kim, S. 2002.Review of S\&T Human Resource Policies in Korea. STEPI (Science and Technology Institute), Seoul, Korea.

Choi, J. 2008. Comparative Study on the Concept and the Motivation of Internationalisation of Higher Education. Education of Religion Research, Vol. 28, No.1, pp.213-232.

KCUE. 2003. A Survey on International Cooperation of Korean Universities, Korea Council for University Education. Seoul, Korea.

Kim, E. 2006.Internationalisation and isomorphic forces in Korean higher education, Perspectives in Education, Vol. 4, No. 4, pp.69-80.

Kim, L. 1997. Imitation to Innovation: The Dynamics of Korea's Technological Learning. Harvard Business School Press, Boston, USA.

Kim, S. and Lee, J. 2006. Changing Facets of Korean Higher Education: Market Competition and the Role of the State. Higher Education, Vol. 52, pp.557-587. 
Kim, T. 2005. Internationalisation of Higher Education in South Korea: Reality, Rhetoric, and Disparity in Academic Culture and Identities. Australian Journal of Education, Vol. 49, No. 1, pp.89-103.

Kwon, K.-S. 2011. The Co-evolution of Universities' Academic Research and Knowledgetransfer Activities of Universities in a Catch-up Country: The Case of South Korea. Science and Public Policy, Vol. 38, No. 6, pp.493-503.

Kwon, K.-S. 2009. Emergence of research and entrepreneurial activities of Korean universities. In: Paper Presented at the Conference on University-Industry Linkages and Economic Performance, College of Social Sciences, Seoul National University, February 27, 2009.

Lee, H., Choi, K., Yoon, J. and Kim G. 1998.A study on the History of Modern Education after Liberation from Japanese Rule. Korean Educational Development Institute (KEDI), Seoul.

Lee, J. K. 2006. Educational Fever and South Korean Higher Education, Revista Electrónica de Investigación y Educativa, Vol. 8, No. 1, pp.1-14.

Lee, Y. et al. 2001. Study on the Systematic Approach to the Effective Internationalization Policy of Universities. Korean Journal of Higher Education, Vol. 12, No. 2, pp.155-205.

OECD. 2009. Globalisation and Higher Education: What Might the Future Bring? Paris, OECD.

Park, S. 2009. The Advancement of Higher Education in Globalised World. Keynote presentation, conference for the promotion of private education. $31^{\text {st }}$, June, 2009. Korean Foundation for Private Education, Seoul, Korea. 